\section{Michele Mazzeo}

Pontifical University Antonianum, Roma

mazzeo.mi@tiscali.it

DOI: http://dx.doi.org/10.12775/BPTh.2017.012
Biblica

et

Patristica

Thoruniensia

10 (2017) 2: 211-227

ISSN (print) 1689-5150

ISSN (online) 2450-7059

\title{
Sacredness, dignity and mystery of human life: from the Bible to our times
}

\section{Świętość, godność i tajemnica życia ludzkiego: od Biblii do naszych czasów}

\begin{abstract}
The author discusses three issues: (1) daily approaches to the dignity and sacredness of human life and their consequences; (2) the sacredness of life to be rediscovered and mediated through the Bible; (3) "humanity/ādām created in God's own image and likeness": dynamic and canonical meaning. At the end he asks for route to be proposed to the sacredness and mystery of life in our days, news and current affairs.
\end{abstract}

Streszczenie. Autor podejmuje się omówienia trzech problemów: 1) współczesnych podejść do godności i świętości życia oraz ich konsekwencji; 2) świętość życia odkryta i przemedytowana w świetle Biblii oraz 3) „człowiek stworzony na obraz i podobieństwo Boga”: dynamiczne i kanoniczne znaczenie. Na końcu autor zadaje pytanie o świętość i tajemnicę życia w naszych czasach.

Keywords: dignity of human being; sacredness of life; bioethics.

Słowa klucze: godność istoty ludzkiej; świętość życia; bioetyka.

$\mathrm{O}$

ur reflection is divided into three parts with a conclusion: 1) daily approaches on the dignity and sacredness of human life and their consequences.

2) The sacredness of life, to be rediscovered and mediated: "Every creature of God is good [...] is sanctified/hagiázetai by the word of God and prayer» (1 Timothy 4,4-5). 3) «Humanity/ādām created in God's own image and likeness»: dynamic meaning and canonical. Conclusions: how to propose a route on the "sacredness and mystery of life in our days, news and current affairs. 


\section{Foreword. Dignity and sacredness of human life: today's approaches and consequences}

Today all people are asking radical questions about their lives, but they also need good answers. We must recognize that this is a universal anthropological question, which calls into question the certainties wich have been acquired. We talk about life, but how you conceive the lifes that you speak about? When life begins and ends? And how does it end? Who decides that life begins or ends? Faced with new opportunities and complex problems of biotechnology applied to life, there are unusual difficulties with different positions, sometimes opposing, think of the difficulty in determining the beginning, the «brain dead and the articulated issue of transplantation organs. These are just some of the questions which ethics and bioethics are trying to bring their contributions, but these are radical questions and are always useful, as stated by Benedict XVI in his speech to the teachers of the Catholic Theological Faculty of Tübingen:

Where are no questions asked, even those that touch the essential and go beyond any specialization, we no longer receive even answers. Only if we ask and if with our questions we are radical, as radical as theology must be [...] we can hope to get answers to these fundamental questions that concern us all. First we must ask. Who does not ask doesn't receive answers. But, I would add, that it is important for theology also the humility to listen to the answers that the Christian faith gives us; the humility to perceive in these answers their reasonableness and make them so accessible again to our time and to ourselves. In this way, humanity is helped to live ${ }^{1}$.

In the Bible there are the principles-based that transcend the boundaries time and cultural space, they give a central place to the person and his relationships and aim to the integral good of the human person. So this International Conference in Torun is a privileged way (for content and dialogical method).

Today's man, is considered both individually and collectively, is confronted every day with moral problems which derives from the development of human sciences and the globalization of communications. As consequence, even true believers have the impression that some certainties of the past are canceled. Just think of the different ways to approach the ethics of violence, terrorism, war, immigration, wealth

1 Benedetto XVI, Incontro con il Collegio dei docenti delle Facoltà di teologia cattolica di Tübingen (21.3.2007). Il testo è consultabile per intero nel sito http://www.vatican.va/ holy_father/benedict_xvi/speeches/2007/march/documents/hf_ben-xvi_spe_20070321_ tu-bingen_it.html. 
sharing, respect for natural resources, life, work, sexuality, research in genetics, family or community life. Faced with this complex issue in recent decades, the Scripture, might have been marginalized in moral theology. What to do when the Bible does not give complete answers? And how to integrate biblical data, when to process a moral discourse on these issues [including the sacredness and dignity of human life] must resort to the lights of theological reflection, reason and science?2.

It has been of the end of World War II, - the most dramatic moments when we interessed that has returned to reflect on «human dignity» in European and American area. It is no coincidence that at the beginning of the millennium you are doing the same, with new horizons of meaning, in Italy in 2017 a new series come out (From the word to the ethos: itineraries for human action today), whose word-driving this sentence of the rabbinic tradition:

«The life of one man is equivalent to the entire work of creation» (Abot de Rabbi Natan 31.1).

The hermeneutical viewpoint from which we place ourselves is the dialogue of Peter, announced in his first Letter: «Sanctify/hagiásate Christ as Lord in your hearts. Always ready to give reason (lógos) to whoever asks you for the hope that is inside us. So, do it with gentleness and respect» (1 Pt 3,15-16). I am a professor at the Pontifical University Antonianum of Rome, and also a student at the Alphonsian Academy in Rome, with a thesis of ethos in the works of Lucan, where the theme of sacredness and dignity of human life is very important.

The term praús/gentleness, kindness, describes the believer's struggle against those who ask, and respect arises directly against God, therefore, it requires a «good conscience/synēidesis agathēn» (1 Peter 3:16) ${ }^{3}$. Peter has learned from Jesus the humble attitude, who renounces to violence and invites: «Learn from me who am meek and humble of heart» (Mt 11:29). So it is not surprising that Paul also defends its position by «the sweetness and goodness of Christ» (2 Cor 10.1), specifying that "gentleness is a fruit of the Spirit» (Gal 5:23).

Decisive is figure out what concept to start from when talking about «sacredness and dignity of life», because we believe that the starting point influences all the thoughts and actions towards human life. The question of what man is, is hardly new (Ps 8.5 to 6 , «What is man... he has been made less than God», Hebrew text), but today it has become a decisive question, because we are moving more and more towards «models «post-human existence (post or-

2 Pontificia Commissione Biblica, Bibbia e morale. Radici bibliche dellagire cristiano, n. 92; M. Mazzeo, «Bibbia e modelli etici-bioetici oggi: analisi e valutazioni», 317-362.

3 Cfr. M. Mazzeo, Lettere di Pietro. Lettera di Giuda. Nuova versione, introduzione e commento, 132-133. 
ganic, bionic, with implants and increasingly synthetic organs) that are heavily eroding the concept of «humanity». The diagnosis, formulated by Günther Anders in "L'uomo è antiquato", of a passage from homo faber to homo creator, is revealing in some ways "prophetic», followed by Francis Fukujama, with its reflections on: Our Posthuman Future: Consequences of the Biotechnology Revolution ${ }^{4}$, they found resctions at an opposite defense, like Nick Bostrom, In defense of Posthuman Dignity in Bioethics ${ }^{5}$, and by the President's Council on Bioethics, Human Dignity and Bioethics; and in the question of Pablo Requena, Sacredness of life. Still it needs for bioethics?'. Even Ronald Dworkin, Life's Dominion $^{7}$, states that:

«Human life has an innate intrinsic value; [...] human life is sacred just in itself; [...] the sacred nature of human life begins when its biological life begins» ${ }^{8}$. However, the idea Dworkin «holiness» that he proposes remains vague (to remember that it is a legal philosopher).

About the concepts of human dignity and sacredness today - as noted - are finding new ways. What does the Scripture have to say about life today? We speak about the second point: «The Sacredness of life, to be rediscovered and mediated».

\section{The sacredness of life, to be rediscovered and mediated: «Every creature of God is good [...] is sanctified/hagiázetai by the word of God and prayer» (1 Timothy 4,4-5)}

As word-driving of this point, we choose a text of the New Testament: «Every creature/ktisma of God is beautiful/kalos and nothing is to be rejected, but should be taken with gratitude/eucharistías; is sanctified/agiázetai by the word of God and prayer» (1 Timothy 4,4-5).

The text of 1Timothy can also be translated: «Everything that has been created by God is good, and nothing must be refused, if you take it with a grateful heart». However ktisma the greek word used here by the author indicates the «creation, creatures» (as ktístēs is the «Creator»), occurring in 1 Tim 4.4;

4 Cfr. G. Anders, L’uomo è antiquato. vol. 2. Sulla distruzione della vita nellepoca della terza rivoluzione industriale; F. Fukujama, Our Posthuman Future: Consequences of the Biotechnology Revolution.

5 Cfr. N. Bostrom, In defense of Posthuman Dignity, 203-214.

6 Cfr. P. Requena, Sacralità della vita. Serve ancora per la bioetica?.

7 Cfr. R. Dworkin, Life's Dominion, 68-101.

8 R. Dworkin, Life's Dominion, 11. 
Gc 1.18; Rev 5:13; 8.9 and indicates «the creatures». Please note that in our letter there is the term with the adjective 1 Timothy 4.4: «Every creature is good/ kalòs», literally «beautiful».

In the passage of the New Testament there are three dimensions that help us to clarify the sense of dignity and sacredness of human life:

a) the first positive affirmation, is in parallel with the second: «Every/pann creature/ktisma of God is beautiful/kalos (and it is more than goodagathós/);

b) no one/oudén is unwrapped/reject (literally throwing away/despise). «Every/pan» is a neuter singular indefinite adjective and means «each, every, everyone. "No/ouden is an indefinite sense is that the whole «every creature of God is good, and nothing to be refused, if it be received with gratitude», «because «is sanctified by the word of God and through prayer, and the author of 1Timothy continues «by offering these things to the brothers, you will be a good minister of Jesus Christ, nourished in the words of faith and of the good teaching/ didaskalia you followed. Avoid stories [«myths/mýthois], old ladies matters/graōdēs. You have to train/gymnázō to true piety/eusébeia» (1 Tim 4,4-7a). The author of 1Timothy faces the problem of dignity and sanctity of life from the root. The reason he brought is based on the positive assessment given by God himself on the work of creation in Genesis 1:31: "And God saw that it was good». Implicitly, he rejects any position that deviates from that pronouncement. Indeed, he adds twice the liturgical component of «thanksgiving» (1 Timothy 4,3-4). The protagonists of this cosmic liturgy are: «the faithful and those who know the truth, and those who eat with thanksgiving return (1 Timothy 4,3). This is the motivation which is the third dimension of the sacredness of life;

c) «because each creature/ktisma of God is beautiful/kalos [...] is sanctified/ hagiázetai by the word of God and prayer» (1 Timothy 4,4-5). Fixed the fundamental point of translation, there is a key term on which positively reflect on our theme and is the verb used to indicate the sanctification of the people «every creature/ktisma of God [...] is sanctified/hagiázetai», and the verb «to sanctify, consecrate/hagiázō» is used here in the present indicative passive, it means «the creature is made holy by God. The passive implies God as agent (is a passivum divinum), a linguistic phenomenon very important in the NT, where the agent of the person who does the action is omitted, to avoid pronouncing the name YHWH. The «truth» of 1Timothy is linked to the synthetic expression that Jesus formulates in John's Gospel: «I am the way, the truth and the life» (Jn 14,6). 


\subsection{What does «sacredness» of life means from the Bible?}

In Christianity, holiness, is referred, as a concept fundamental theological, to God, who revealed himself to us in a unique, and unsurpassed in Jesus of Nazareth, called «the Holy One of God/ ho hágios tou theou» (Jn 6: 69). This is the meeting of man with «another different from himself», that Rudolf Otto defined it as, "the numinous», "the Wholly Other». Now even «the Holy» Bible has its deepest foundation in what phenomenologists of religion called «the numinous», a term derived from the Latin numen (divine power) and recalls the origin and end of life. Such is the experience of Moses and the people at Sinai: firstly rejecting (mysterium tremendum), and second, that attracts (mysteryum fascinans). An extraordinary example of this is the experience of Moses and the burning bush in Exodus 3.

Wolfgang Gantke, helps us:

The saint is not what is at our disposal, what escapes in principle the right to dispose of and which poses insurmountable limits to idealization of human tendencies. Just in its capacity class limit and protector of the holy life, the saint could be summed up in a new and deeper meaning "risk society". In this perspective, the discussion on the holy is not really about a story of the past but a major theme of the future. In the theological context behind the issue of the saint it is hidden the "question of God", whose human relevance could be rediscovered after the predictable failure of many attempts «technocratic» so human self-redemption, became attempts "immeasurable".

The lexical group that regards the «sanctity» is large in the NT: «holy/hágios» occurs 230 times, and in 90 cases out of 230 is combined with «spirit/ pneûma», to form a fixed formula, "Holy Spirit», which most often it is the work of Lucania (13 in the gospel of Luke, in Acts 41). The verb «to sanctifs/ hagiázō» is used 17 times and 11 to passive assets. Are or are sanctified (passive) the name of God (Mt 6,9; par. Lk 11,2), believers (Jn 17,19b; Acts 20:32; 26,$18 ; 1$ Cor 1,$2 ; 6,11 ; 7,14 \mathrm{bis} ; 2$ Tim 2:21). All are sanctified through the only Son (Heb 2,11b; see. 10,10.14), everything that God made/created (1 Timothy 4.5), and finally Christ himself, who is sanctified by the blood of the covenant (Heb 10:29, quote from Ex 24.8). Subject implicated into the sanctification of passive formulations is quite often God (passivum divinum) ${ }^{10}$.

9 W. Gantke, «Santo», 61.

10 Only in Revelation 2:11 «the holy is still sanctify» (I hágios hagiasthētō éti), the passive is translated as «medium», literally: «Who is holy continue to remain holy». 
Should be noted that there are three terms that indicate the sacredness in the NT books: uses 230 times the word «holy/hágios (with 20 appearances in Luke and 53 in Acts 20 in Romans and 18 Jews). The verb «sanctify/hagiázō», occurs 28 times, «sanctification/ hagiasmós» 10 times (the latter word not found in the Gospels and Acts). In contrast to the extra-biblical literature, Hellenistic, «holy/ hágios» in the Bible of the Septuagint is very frequent (about 700 times, mainly as a Hebrew translation qādôs and qōdeš where prevails the idea of «separate» from the profane and "consecrated as "property of God", that is a precious reality in relationship with God), also it serves to form new words (neologisms) sanctify/hagiázō «for example is introduced in Genesis 2.3; with «sanctification/hagiasmós» in Jeremiah 6:16 (2 Macc 15.2; Sal 29.2, all are 5 appearances). We wonder: why does this lexical phenomenon happen? The exegete $\mathrm{H}$. Balz observes that

It seemed appropriate hágios as the equivalent especially because - as qadoš - made it possible to express the holiness of God as a requirement established in its power and perfection. Consequently man is consulted from a reality placed outside and above the world, and so he could become an epithet of God (Lev 19.2; 1 Kings 2.2; Is 31.1; Os 11.9), its name (Is 60.9, his Spirit (Ps 50.13), its places (Ex 3.5; Lv 7,6; Ps 2,6), the entire cultural sphere, that is, everything in the world directly owned and dedicated to God $^{11}$.

Even on the text of 1 Pt 1,15-16 («like the Holy who called you, be holy yourselves in all your conduct, for it is written: «You shall be holy for I am holy»), where holy is opposed to the wishes of the past, Balz says: «Holiness, or sanctification. It is therefore the acceptance of God's holiness by believers, so that they can place themselves in communion with him, not a gradual move towards an ethical-religious perfection».

1) In this perspective, the saint is a definition of the essence of God defined as «person». God is «the saint/ho hágios» (1 Pet 1:15; Lev 19.2), who created the world and acting in the world through the «Holy Spirit». In the cultic language of Torah are said holy men, things, times, spaces (temple) and cities (Jerusalem as a holy city). In these cases the term «saint/qadoš indicates the separation from that which is impure and profane. Holy is therefore primarily a cultural concept and vital ritual.

2) Israel is sanctified with the holiness of God and this is called «a holy people» chosen by God (Ex 19.6), because «God is the Holy one of Israel» (Isaiah 12.6), and as such, a higher power that imposes respect and obe-

11 H. Balz, «ágios», 47. 
dience, as shown in the saving history (qadoš also indicates the «heaviness» that is, the importance).

3) In the New Testament Christ-focused, lacking a cult place in relation to people and holy objects. God is called by Jesus «Holy Father» (Jn 17:11). The whole «life» is a «holy» cult. Thus with the «Our Father» Jesus teaches us to implore the «sanctification of the» name «(Mt 6,9, hagistathètō, to use a passive verb).

4) In front of the "profanation» high even in today's Europe program, the speech of the «holy», the «sanctity» of life gives the impression of a foreign body in a world that is becoming increasingly de-Christianized and irreligious. This de-sanctification process is already well advanced and it is revealed by the discussion around the show on Sunday and one on human life. The sanctity of human and Christian life comes from the holiness of God (1Peter 1:16; quotation from Leviticus 19.2; cf. also Ap 22.1). From this point of view Peter recalls with a new term the goal of conduct/anastrophe life of believers, life «in the sanctification/hagiasmós worked by the Spirit» (1 Peter 1.2), as does Paul in Romans 15:16: «To be a minister of Christ Jesus to the nations, fulfilling the sacred ministry of proclaiming the gospel of God to the Gentiles become an offering pleasing, sanctified/hègiasménē by the Holy Spirit».

«Sanctify/hēgiasménē» is used in the passive, it is still another passivum divinum. So it becomes easier to understand the ministry that is based on divine grace "given» (dotheiesan, another taxable divine). The Gentiles are described as acceptable and sanctified by the Spirit offered. All believers, can offer their bodies, ie themselves in sacrifice (as it says in Romans 12,1-2): "Offer your bodies as a living sacrifice, holy and acceptable to God...». The Letter to the Hebrews 10:10 says: «We have been sanctified through the offering of the body of Jesus Christ once for all». The use of the term «once and for all unicity», original of the letter to the Hebrews shows that Christ offered Himself «once for all» and we are purified, sanctified from oblation of «sanctifying done once and for all (action that half-time value).

\section{3. «Humanity/ādām» created «in the image and likeness of God»: dynamic and canonical meaning}

The Hebrew term a àdm means «man/humanity» and has no plurality, thus the life we all have is a gift that we can only receive and live. Life is not an abstract static gift but a gift «project» which is forever dynamic. Such as also the reality of being a «son» in the parable of the «return of the lost and rediscovered 
child $»^{12}$ is a gift forever but life is a relationship that the child discovers in its fullness only after he has left home. Gradually when he is away from the Father and among the pigs and he finds out that the pigs - among whom he is living eat carobs while he is treated as less than animals ("he would have wanted to eat carobs but no one gave him», Lk 15,16). Then he realizes that in such a situation he has a lower dignity than the animals he is taking care of and nourishing, and that he can not give himself dignity, so something that always changes happens: He came back to himself and said: «How many wage-earners in my father's house have bread in abundance and me, I'm starving here! I will rise, I will go to my father and I will tell him, father ... I am no longer worthy/áxios to be called your son/ouós sou. Treat me as one of your wage-earners/místhios» (Lk 15: 17-19).

First, he raises his feet to go away, toward freedom, far from the Father. The journey of the youngest son, his departure from the father's house, his moral decay, the stages of his conversion ("he was entering into himself», Lk 15,17, «I will go to the father» Lk 15,18) are parenetic details in which we all can recognize his/her own experience of distance from God. However, the reconciliation that only the father can give and that he grants as the undeserved gift of filiation follows. The father respects his son's freedom, he grants him part of his "patrimony» (bios, literally «life», earthly, Lk. 15:12) and by losing the received goods he loses every right before him. Sin is in such loss of paternal patrimony more than in the lush life that it is not mentioned. The personal catastrophe is aggravated by a natural catastrophe: famine, not rare in the semi-desert areas of the East. Thus he is reduced to total poverty and dependence on the others. At this stage, the child decays right from the Torah/Law and the religion of his people and two acts specify it (Lk 15:15): 1) he joins a citizen who breeds pigs so revealing to be a pagan; 2 ) he is the keeper of the pigs who are the unclean animals for excellence (Lv 11,17). Even the pigs were best fed than the son and the latter could not even «feed himself» (some authoritative manuscripts such as the $\mathrm{P}^{75}$, the Vatican, the Sinaitic report even the most vulgar expression «filling their belly»), with carobs, namely the pods used to fatten pigs and horses.

The description of the inner event (the conversion) is transparent: the journey and misery recall the loss of man's glory, the image of God; the contact with pigs is a symbol of death due to sin. A rabbinic saying states «damn the man who breeds pigs» (b.Bab.Q 82b). Eating carobs is important in the Judaic tradition for a rabbinic proverb says: «When the Israelites are forced to eat car-

12 Eegete P. Grelot titled "the father and his children", cf. «Le père et ses deux fils: Luc XV, 11-32», 321-348.538-565. 
obs, they do convert» ${ }^{13}$. Having reached the bottom, the boy, «falls back into himself", he becomes aware of his sin. In the context of alliance, the breaking of human relationships also imply breaking with God, so Luke changes the preposition: «I have sinned against (eis) Heaven (namelym God) and before (enōpion) you» (Lk 15:18), a variation in his style conforming to Es 10,6. His decision to return to his father knowing he has no longer rights. He hopes to be treated as a daily worker/misthios. The miracle well represents the situation of the man having no merit to offer nor titles to claim and thinks he has lost dignity. Sonship is a mere gift. The son goes back on his way without knowing what will happen. Thus, the entire attention is focused on the father's behaviorinitiative described in $\mathrm{Lk}$ 15,20, one of the most moving step of the whole Bible.

a) The father sees him first from afar and does not wonder how ever: he never gave up loving him as his own son.

b) The father is upset to his bowels: a central verb already expressing JHWH's sense of the poors, and of Jesus to the needy (Mc 1,41; 6,34; Lk $7,13)$.

c) He starts running: a little dignified behavior for a man of his age and authority.

d) He throws to his son's neck and then he prevents the boy from humiliating himself by throwing himself at his feet as the young man had planned to do when back.

e) He kisses him, a sign of forgiveness (2 Sam 14,33) and of communion, without taking into account the state of impurity due to contact with pagans and pigs.

A surprising behavior of a father whose authority is undisputed, and whose free and overwhelming love is beyond any rule/nómos and opens to a new ethos on the dignity and sacredness of life recalling the «origin» (Gen 1,1-2,4a). You will understand how life is really «beautiful/kalos and that no life is to be rejected indeed to be taken with gratitude because it is holy» (see $1 \mathrm{Tm} 4: 4-5)$.

The son begins to recite the confession he had prepared before («I will tell him, father, I have sinned...», Lk 15,18), without being able to finish it («treat me as one of your wage-earners», literally «daily workers», Lk 15,18b). The father's behavior now renders such a request inadequate by now. Three requests from the father to servants to the confession of the son show the reintegration into the original filial relationship:

13 For the texts cf. H.L. STRACK, P. BILLERBECK, Kommentar zum Neuen Testament aus Talmud und Midrash, II, 214. 
a) the gift of the long dress/stole, a party dress that serves to honor the guest or to signify his dignity as a son, dressed for the saved (Ap 6,11;7,9,13, etc.).

b) the ring/daktýlios to the finger ( $\operatorname{Lk} 15,22)$ : this is a ring with a seal so that the boy is restored to his filial dignity with all the associated authority and powers (compared to the home and society field);

c) sandals: they are the sign of the free man (the slave walked barefoot).

The father's surprising love surrounding the son is the expression of absolute freedom and makes him re-born: it is a new life. The father recreates him. Here comes well that it is not the man who is saved, it is not the man who gives himself dignity: it is a reality that he belongs from within and nothing and no one can scrap it since "sacredness» of life is original to the human beings and it is connected to that one of God the Father.

In the second scene this is shown in a simple way in the appealing dialogue for us between the father and his older son, who has just arrived; he hears the festivities and asks what it is happening by harsh tone while the father's tone comes out again and becomes particularly affectionate: «Son/téknon, you are always with me, what is mine is yours» (Lk 15,31). The father understands his reaction and does not reproach him and emphasizes his personal love for the eldest, and reminds him at a legal level that as a legitimate heir he already belongs the whole property: «you are always with me, what is mine is yours». On a more human level, the value of family unity is revealed: the image of permanent communion with the father urges us to a religious level: the essential for the believer is the relationship/communion with God the Father.

Hence the new logic proposed by the father of the love of God for what is lost: «We're going to feast!» (Lk 15:32); this is Jesus' logic and of the new times. To the aggressive «this son of yours» of the first-born (Lk 15: 30), the father answers, "this your brother» (Lk 15:32). An invitation to truly acknowledge as his brother this unlucky brother back home in his real dignity: son of his father, brother since «man» $(\bar{a} d \bar{a} m)$. If the eldest son wants to remain in communion with his father, he must accept his brother as the father himself had welcomed him back. If he is going to feast with his brother, if he will enters the same logic as his father's love, then he himself will enter the «house» and he will experience in a new way what «being a son and being a brother» means.

What decision will the eldest take? The answer is up to you, me, and every reader/hearer of this narrative about dignity and sacredness of human life awaiting the return of the Lord. Dignity of life is an appeal that remains open the same as a refrain: we will enter into the prospect of having received the gift of being children, being brothers, never forgetting that this story of the two sons recalls another original story, the one of the two brothers, Cain and Abele 
(Genesis 4) that allows us to deepen the last issue of our intervention on the sacredness of man's life created «in the image and likeness of God» (Genesis $1,26-27)$.

In the Bible from Genesis to Apocalypse the human being is surrounded by the mystery of God the Creator, because it is created in his «image and likeness» (Genesis 1,26-27), namely it joins his mysterious depth and, for free gift of his grace, his endless life that begins from the present. The identity of «Eve», meaning "life», that is the mother of the «living», and "Adam/ādam [= humanity]», meaning precisely «human being, humanity», settles into being of God because nothing can undermine their dignity as human being since they both sink into the humanity as God's children, created/blended with his «image and likeness», an ontological dimension they are requested to transmit because Adam lived, he joined Eva.

"And he made a son in his likeness, according to his image» (Genesis 5: 3).

In Genesis 1 creation is made through the word. Not only doing, not just splitting, but also talking. And God said «let there be light, and there was light». And 10 is a significant number because if these are the 10 words of creation, to those reading immediately comes to mind the 10 words of the decalogue, a deep relationship between the two realities. Because we must remember that the revelation of God's original plan of life in creation as a gift originates in a death environment because it was born during the exile, when people were deported and living such a terrible death experience of real death not only because they are decimating them but because of that more tragic death that is not understanding the meaning of what is happening and what the end has done to God. When Israel is deported to Babylon comes the radical questions: for God had made the promises, the earth, the king, the temple and then it's all over? Because there is nothing now, only crisis, darkness, pain and death. It looks like the accounts do not come back that God promised you something and then you take it away. Terrible experience, only those who made it can understand. You are in the middle of the street and you do not know where to go and you do not know who you can turn to: there is no one. In this situation, this great hymn to life is born, which is Genesis 1 . That in the historical crisis of faith in death, it states: no! God is there and he is the God of life, he has always existed, and for that he is forever and is the good and good God who does good and good things, indeed «very beautiful» (Genesis 1:31). The text contains a question: Will the reader, man, the point of view of God on creation and on human life be taken? 


\section{Conclusions: how to propose an itinerary on the «sacredness and mystery of life» in our days, novelty and recent event}

The itinerary on the sacredness of life together with being all of us «the image and likeness of God» in a dynamic sense (of becoming), can be a credible and talkative paradigm for today's man? How and why?

Four observations show a possible itinerary and such to start a new interdisciplinary research, without losing the old ones.

1) Be humble and listen to the questions of men and women of our time, learning Jesus' method of Jesus to ask ourselves and ask the others new questions before giving answers and making/asking radical questions. Learn to «narrate», how we have seen a story of dignity with the parable of the father and the two children, never lost, because the narrative approach emphasizes «how narration constitutes the original language of ethics, since it articulates - at a pre-conceptual level - an image of good $[\ldots]$, the same double significance of narrative as it is endowed with an epistemological dignity and, at the same time, an irreducible rhetorical component reproducing the mode of the revelation of good within the desirable relationship, where desire makes something of good known just when it reveals it as attractive» ${ }^{14}$.

Man is a narrator aspiring to truth. In the light of these observations, McIntire introduces the concept of télos, «fulfillment» with reference to human life, through which a fundamental thesis emerges: «man in his actions and in his practice the same as in his fiction is essentially an animal that tells stories. It is not essentially but it is through his story a storyteller of stories aspiring to the truth» ${ }^{15}$.

Narration is an epistemological category in which wee can observe the transition to the practical scope on the basis of the link between narration and human action. Hannah Arendt, says «narrative reveals the meaning without making the error of defining it» ${ }^{16}$.

It can be said that the synoptic Gospels offer three variants of points of view for the same story told, that is, the story of life, death, and resurrection of Jesus of Nazareth. The reason is that each synoptic Gospel Matthew, Mark, Luke - are distinguished by the narrative crystallization

14 F. Cattaneo, F. Cattaneo, Etica e narrazione. Il contributo del narrativismo contemporaneo, $\mathrm{xx}$.

15 A. McIntyre, Dopo la virtù. Saggio di teoria morale, 258.

16 H. Arendt, Isak Dinesen (1885-1962), 169. 
of a narrator's point of view, and it is possible to reconstruct that point of view that holds all the narrative strategy present in the text. In this sense we will talk about the point of view of Matthew, Mark, or Luke.

This leads us to wonder then what is the point of view? It is the relationship the narrator has with the story told. The point of view is a cognitive positioning that the narrator adopts when he tells the story he wants to present and he applies to all elements of the narrative, whether they are people, objects, or values. There is no pointless story,

as there is no picture without the movie camera or the camera being positioned at a specific point determining its field of vision. As always in the photographic metaphor, the narrator's point of view is not made up only of a chosen place, a chosen temporality, a chosen description, a description of the interiority of the characters, a choice of language (adopted by the narrator or given to characters) and the most crucial element, in my opinion, from a system of values grounding his assessment of characters. More specifically, in this case, the narrative's point of view will be discussed ${ }^{17}$.

2) The second one is to communicate with the sciences and with the new horizons of meaning brought by the techniques applied to life on the horizon, without pre-comprehension, full acceptance or preventive condemnation.

3) The third one is the formative commitment to new generations at different levels (researchers, teachers, society and young people), above all of socio-religious institutions. A special place within the training processes is given to the formation of consciousness/syneidesis, because it becomes - as said at the beginning - the hub of the whole decisions that each person takes.

4) «Life indelibly carries on its own truth ${ }^{18}$, which is dynamic «is the Gospel that reveals the integral truth about man and his moral journey», as the Pope John Paul II tell'us ${ }^{19}$. But what does that mean? It means that we have received the gift from which the commitment to rediscover and to do as the disciples of Emmaus arises: to let us learn from the risen Jesus who «explains the Scriptures, while we are marching toward» our homes (Lk 24: 25-35). Nowadays that word really speaks, without hypocrisy, it remains a «mystery/plan». This is a road that from the First to the New

17 D. Marguerat, Il «punto di vista» nella narrazione biblica, 123.

18 Giovanni Paolo II, Evangelium Vitae, n. 48.

19 Giovanni Paolo II, Veritatis Splendor, n. 112. 
Testament tells us how we must do, but «how» we have to do in today's dialogue is all to be invented ${ }^{20}$.

The lurking risk is that we want to have a ready-made speech, resolute answers; we do not want to walk like the Jewish people did while leaving Egypt. Indeed, the sense lies precisely in the "way» to the goal where we experience sanctification in the meeting with «the Saint». Therefore, crucial is the method owing to which we allow ourselves to postpone to our The care of Life. Bible and Bioethics and Fragility and preciousness of Human Life $e^{21}$.

In the Bible, the beginning and the end of human life are linked to all the questions of meaning marking the stages of development by acting on the events of existence in a mysterious but uninterrupted and unified way, as Romano Guardini has intuited:

Beginning and end are mysteries. The distinction between the beginning of life, birth and childhood does not mean that life moves from a starting point left behind, but that this starting point accompanies life in its development. Birth and childhood are vital elements in man: for the individual they are analogous to the one that for the universal history are the origins and of the one that is worshiped in the myths of the foundation and in the figure of the ancestors. Such element acts throughout life till the very end. Conversely, however, the end acts backwards until the very beginning. Likewise, the start of the melody determines its shape throughout its subsequent development, as well as the end shapes melody by running it backward. Life is not a scattering of parts, but a whole that - with a little paradoxical expression - is present at each point of development ${ }^{22}$.

On the one hand from this lexical itinerary we observe the different view of the human being in the Bible (Semitic-Hebrew) compared to Western anthropology, matured more on the Greek-Latin cultural field. Human being is thought of as a dynamic unity in relation to the others, in the world (other living things), in front of God.

What distinguishes biblical anthropology is the religious horizon based on two great bases for our time on human life: creation and resurrection. Two specific terms can be used: proto-logy (primordial discourse on life), and eschatology (ultimate talk about life and creation). Creation is the starting point

20 Which tools, with what resources? Only the parameters of justice, love, dignity, which are most useful.

21 Cfr. M. Mazzeo, Cura della vita. Bibbia e bioetica; M. Mazzeo, Fragilità e preziosità del vivere umano. Bibbia ed etica di fine vita. Dilemmi e responsabilità.

22 R. Guardini, Le età della vita. Loro significato educativo e morale, 73-74. 
or promise of God's plan for the world and human adventure. Life is a promise as well, a project, a mystery/mysterryon, hence the presence of the resurrection, also called «new creation», the point of arrival and fulfillment of the promise. From the ethical and bioethical point of view, this involves the logic of gratuitousness and freedom in the relationships of the person living in the world with the other living.

Freedom, inseparable from the free creation, sprouts and grows within human history on the symbolic soil of the exodus and the resurrection Easter. Without the exit from fear, which generates idols, it is impossible to live and exercise freedom. The last exodus is the overcoming of the anguish of death extinguishing the desires and corroding all plans of the human being, made for the full and endless life ${ }^{23}$, "when the mystery/mystêryon of God will be fulfilled, as he has announced (Ap 10: 7).

How do to deal with the challenges of life today? An answer to this dilema is offered by rabbi Hillel. Who when confronting these challenges of life, invited his disciples to come out from obscurity, and to take responsibility in situations in daily life, always asking three questions:

- If I don't do it, who will do it for me?

- If I do it for myself, who am $\mathrm{I}^{24}$ ?

- If I don't do it now, when will I do it?» (Pirqé Abot 1,14).

\section{References}

Anders G., L’uomo è antiquato. vol. 2. Sulla distruzione della vita nellépoca della terza rivoluzione industriale, Bollati Boringhieri, Torino 2003.

Balz H., «ágios», in H. Balz, G. Schneider (edd.), Dizionario Esegetico del Nuovo Testamento, Paideia, Brescia 1998, I, 47.

Benedetto XVI, Incontro con il Collegio dei docenti delle Facoltà di teologia cattolica di Tübingen (21.3.2007) [online:] http://www.vatican.va/holy_father/benedict_xvi/speeches/2007/march/documents/hf_ben-xvi_spe_20070321_tu- bingen_it.html.

Bostrom N., In defense of Posthuman Dignity, Bioethics 19/3 (2005), 203-214.

Cattaneo F., Etica e narrazione. Il contributo del narrativismo contemporaneo, Milano 2011.

23 R. Fabris, «Corpo, Anima e Spirito nella Bibbia», 358.

24 The text in this expression is enigmatic and another translation is possible: «If I do it for myself, I am lost». 
Dworkin R., Life's Dominion: An Argument About Abortion, Euthanasia, and Individual Freedom, Knopf Doubleday Publishing Group 1994.

Fabris R., «Corpo, Anima e Spirito nella Bibbia». Dalla creazione alla risurrezione, Assisi 2014.

Fukujama F., Our Posthuman Future: Consequences of the Biotechnology Revolution, Profile Books, London 2002.

Gantke W., «Santo», in P. Echter, I Concetti fondamentali della teologia (BTC 142), Queriniana, Brescia 2008, IV, 61.

Giovanni Paolo II, Evangelium Vitae.

Giovanni Paolo II, Veritatis Splendor.

Guardini R., Le età della vita. Loro significato educativo e morale (prefazione di Virgilio Melchiorre), Vita e Pensiero, Milano 1992.

Mazzeo M., «Bibbia e modelli etici-bioetici oggi: analisi e valutazioni», in Spiritus est veritas $(1 G v 5,6)$. Miscellanea in onore del prof. mons. Armando Augello per il suo $75^{\circ}$ compleanno, E. Della Corte, V. Lopasso, S. Parisi (edd.), Soveria Mannelli (CZ) 2017, 317-362.

Mazzeo M., Cura della vita. Bibbia e bioetica, Dehoniane, Bologna 2015.

Mazzeo M., Fragilità e preziosità del vivere umano. Bibbia ed etica di fine vita. Dilemmi e responsabilità (Parola ed ethos 1), Aracne, Roma 2017.

Mazzeo M., Lettere di Pietro. Lettera di Giuda. Nuova versione, introduzione e commento, Paoline Milano $2016^{2}$.

Pontificia Commissione Biblica, Bibbia e morale. Radici bibliche dell'agire cristiano, Città del Vaticano 2008.

Requena P., Sacralità della vita. Serve ancora per la bioetica?, Soveria Mannelli (Cz) 2013.

Strack H. L., Billerbeck P., Kommentar zum Neuen Testament aus Talmud und Midrash, II, 214. 